\title{
Invasion by Conyza sumatrensis alters soil microbial community structure in urban ecosystems
}

\author{
Nazima Rasool ${ }^{1}$, Zafar A. Reshi', Damase P. Khasa ${ }^{2}$, Mudasir Roshan ${ }^{1}$ and Manzoor A. Shah ${ }^{1 *}$
}

\begin{abstract}
Introduction: Whether invasive plants stimulate or inhibit the soil microbial diversity is still an open question. Despite large-scale invasion by Conyza sumatrensis (Retz.) E. Walker in the urban ecosystems of the Srinagar city of the Kashmir Himalayan region, limited information exists on its impact, particularly, on the belowground microbial diversity. The present study was thus conducted to compare the soil microbial (bacterial and ascomycetous fungal) diversity between the sites invaded by C. sumatrensis and un-invaded (control) sites.
\end{abstract}

Methods: Soil metagenome was extracted from C. sumatrensis invaded and un-invaded plots at the three study sites. A total of six plots $(5 \times 5 \mathrm{~m}$ each in size), including three invaded by C. sumatrensis and three un-invaded plots were nested within each study site. DNA after amplification was subject to denaturing gradient gel electrophoresis (DGGE); the bands were extracted from the DGGE gel, re-amplified, and sequenced for identification of the species.

Results: The number of bacterial species was reduced in the invaded plots at two out of the three sites while as it was relatively higher in the un-invaded plots with many species exclusively found in these plots. Fungal species richness was higher in the invaded plots compared to the un-invaded plots at all the three sites. Also, more fungal species were found to occur exclusively in the invaded plots without being represented in the un-invaded plots.

Conclusions: Invasion by C. sumatrensis alters soil microbial community structure in the urban ecosystems in the Kashmir Himalaya. How this species does so and what benefits does it draw from such alteration promise to be an interesting future discourse.

Keywords: Conyza sumatrensis, DGGE, Kashmir Himalaya, Plant invasion, Soil microbes

\section{Introduction}

Biological invasions are feared to become fiercer in the near future due to substantial rise in the global trade and transportation, which means that the ecosystems as well the economies in many countries would be at a higher risk of harm in the coming years (Perrings et al. 2005; McCullough et al. 2006). Thus, studies on invasive plants and animals become all the more important in the present scenario. The first step in the control of such species is to identify the species with the greatest impact (Lavoie 2010). Invasive species are causing havoc in urban ecosystems as the developing cities make rather

\footnotetext{
* Correspondence: mashah75@yahoo.com

${ }^{1}$ Biological Invasion Laboratory, Department of Botany, University of Kashmir, Srinagar 190 006, Jammu and Kashmir, India

Full list of author information is available at the end of the article
}

the preferred habitats for such plants which being mostly ruderal are capable of rapid colonization in disturbed habitats (Dar et al. 2015). While the effects of plant invasions on the aboveground species diversity are well studied (e.g., Marchante et al. 2008; McKinney and Lockwood 1999; McKinney 2004; Rooney et al. 2004; Taylor et al. 2004; Shah et al. 2014a) largely in natural systems, studies dealing with the impact of invasive plant species on belowground microbial diversity in urban ecosystems are very rare. Notwithstanding cryptic nature of soil microbes and some methodological limitations for their study ( $\mathrm{Li}$ et al. 2006), major changes in the composition and function of soil communities due to plant invasions have been reported with significant influence on soil $C$ and nutrient dynamics (Bohlen 2006; Ehrenfeld 2003; Kourtev et al. 2002; Wolfe and 
Klironomos 2005; Yelenik et al. 2004). For instance, a meta-analysis by Liao et al. (2008) revealed large increase in the pool sizes of aboveground and belowground C (133 and $5 \%$ ) and N (86 and $112 \%$ ) due to plant invasion and so was the case with litter and soil $\mathrm{C}$ pools as well. Not only did $\mathrm{C}$ and $\mathrm{N}$ content increase in plants but such an increase was also recorded in soil and soil microbes (Liao et al. 2008). Interactions of alien invasive species with soil sub-system in their nonnative range may facilitate not only their own establishment and spread but also invasion of by other species as well, a phenomenon known as "invasion meltdown" (Simberloff and Von Holle 1999).

Conyza sumatrensis is an annual herbaceous member of sunflower family (Asteraceae), native to South America with rather cosmopolitan distribution and tendency to be invasive in many regions including Kashmir Himalaya, India. The rapid range expansion of this ruderal species locally may be attributed to the production of a large number of small, wind-dispersed seeds, ranging to over 200,000 seeds per plant (Sansom et al 2013), high resistance to diseases, herbivory, and herbicides (Santos et al. 2014a, 2014b). It is pertinent to mention that recent transcontinental comparison of the impact of Conyza based on field studies, greenhouse experiments, and individualbased models revealed its strong suppressive impact on native plant diversity in non-native regions but not at home (Shah et al. 2014a). Very recently, Shah et al. (2015) showed that Conyza harbors more arbuscular mycorrhizal diversity in native range than non-native range. Whether such patterns in the impacts of Conyza hold true for the other belowground communities as well is still an open question. To evaluate the impact of $C$. sumatrensis on soil bacterial and fungal communities, we used the high-throughput technique of denaturing gradient gel electrophoresis (DGGE). DGGE is one of the important approaches to study the shifts in soil microbial communities subject to various kinds of stresses. As such, this technique has been used in several studies carried out to assess the impact of invasive plant species on soil microbial community (e.g., Nie et al. 2010; Yannarell et al. 2011; Zhang et al. 2010). The fundamental question asked in the present study was whether or not $C$. sumatrensis alters soil microbial communities in the urban ecosystems of the Kashmir Himalaya.

\section{Methods}

\section{Study species}

C. sumatrensis, native to South America (Anastasiu and Memedemin 2011; Santos et al. 2014a, 2014b), commonly known as tall fleabane or broad-leaved fleabane, is a cosmopolitan species and is found frequently in abandoned fields, roadsides, and waste areas (Hao et al. 2009). It is widespread throughout the USA, Western
Europe, and around the Mediterranean Basin (Thebaud and Abbott 1995) and also occurs in central Africa, Australasia, Central America, and Japan (Sansom et al. 2013). In the Kashmir Valley, the plant species is found mostly in ruderal (disturbed) habitats within the altitudinal range of $1600-2500 \mathrm{~m}$ asl. The plant is an annual herb, 1-2 $\mathrm{m}$ tall. The root is short, tap root with a secondary fibrous system. The seedlings develop a basal rosette which deteriorates after stem begins to elongate. The leaves are $4-10 \mathrm{~cm}$ in length and $5-12 \mathrm{~mm}$ width and are grayish green in color. The leaves become progressively smaller up the stem. The flower heads are small inconspicuous and occur at the top of the central stem. The fruit is an achene, $1-\mathrm{mm}$ long tapered from the base to the apex. Each plant produces over 200,000 winddispersed seeds ensuring wide dispersal of the species.

\section{Soil sampling}

All the three sites (site I, site II, and site III) invaded by C. sumatrensis were located in an urban setup-the Srinagar city of J and K State in India $\left(34.0897^{\circ} \mathrm{N}, 74.7900^{\circ}\right.$ E; $1600 \mathrm{~m}$ asl). At each site sub-sites (plots, $5 \times 5 \mathrm{~m}$ each in size) invaded by C. sumatrensis and those not invaded by it (now on referred to as un-invaded/control plot) were demarcated. Invaded and un-invaded plots at each site were roughly $10 \mathrm{~m}$ apart. Ten replicate soil cores (3 $\mathrm{cm}$ diameter), from a depth of about $10 \mathrm{~cm}$, were drawn from invaded and un-invaded plots from each of the study sites. At each site, soil from the replicate cores was mixed to constitute a composite sample. The soil was sieved through $2-\mathrm{mm}$ mesh and stored at $4{ }^{\circ} \mathrm{C}$ till the analysis was done. The structural analysis of the sampled soil was carried out at the Molecular Biology Laboratory, Centre for Forest Research, Université Laval, Quebec, Canada.

\section{DNA extraction}

DNA was extracted from $0.25 \mathrm{~g}$ of soil using MoBioPowerSoil ${ }^{\circ}$ DNA Isolation Kit following manufacturer's protocol (Medicorp Inc., Montreal, Quebec, Canada). The DNA after extraction was stored at $-20^{\circ} \mathrm{C}$. For amplifying bacterial 16S ribosomal RNA (rRNA) gene, universal bacterial primers 907r (Lane et al. 1985) and 358f (Muyzer et al. 1993) were used. Universal eukaryotic primer ITS1 (White et al. 1990) in combination with ITS4A (Gardes and Bruns 1993) was used for amplifying soil Ascomycete DNA. The GC-clamped versions of $358 \mathrm{f}$ and ITS1 were used to stabilize migration of PCR amplicons in DGGE gel.

\section{PCR conditions for bacteria}

PCR reaction for bacterial amplification was run in final volume of $16 \mu \mathrm{L}$. Each $16 \mu \mathrm{L}$ reaction mixture contained $1 \times$ reaction buffer, $1.25 \mathrm{mM} \mathrm{MgCl}_{2}$ (Roche Applied 
Science, Laval, Quebec, Canada), $0.2 \mathrm{mM}$ dNTPs (GE Healthcare, Baied'Urfe, Quebec, Canada), $0.3 \mathrm{mM}$ each of the two primers (907r-GC and 358f) (Invitrogen, Burlington, Ontario, Canada), 400 ng non-acetylated BSA (New England Bioloabs, Mississauga, Ontario, Canada), and 0.025 uTaq DNA polymerase (Feldan Bio, Montreal, Quebec, Canada) per $\mu \mathrm{L}$ reaction mixture. PCR was carried out at following conditions: initial denaturation at $94{ }^{\circ} \mathrm{C}$ for $5 \mathrm{~min}$, followed by $94{ }^{\circ} \mathrm{C}$ for $1 \mathrm{~min}$; annealing at $55{ }^{\circ} \mathrm{C}$ for $1 \mathrm{~min}$; and elongation at $72{ }^{\circ} \mathrm{C}$ for $3 \mathrm{~min}$ and a final elongation at $72{ }^{\circ} \mathrm{C}$ for 10 min pause at $4{ }^{\circ} \mathrm{C}$. The 25 PCR cycles were run for amplification in Eppendorf Master Cycle EpGradient $\mathrm{S}$ thermal cycler (Eppendorf Canada, Burlington, Ontario, Canada). The amplification products were quantified using Gene Tools software from SYNGENE (Invitrogen, Burlington, Ontario, Canada).

\section{PCR conditions for fungi}

PCR reaction was carried out in final volume of $15 \mu \mathrm{L}$. Each $15-\mu \mathrm{L}$ reaction mixture contained $1 \times$ reaction buffer (Feldan Bio, Montreal, Quebec, Canada), $0.25 \times$ BS (Feldan Bio, Montreal, Quebec, Canada), $0.2 \mathrm{mM}$ dNTPs (GE Healthcare, Baied'Urfe, Quebec, Canada), $0.5 \mu \mathrm{L}$ each of the two primers ITS1-GC, ITS4A (Invitrogen, Burlington, Ontario, Canada), $1 \mu \mathrm{L}$ DNA template, and $1 \mu$ per reaction of taqDNA polymerase (Feldan Bio, Montreal, Quebec, Canada). For amplifying fungal DNA touchdown, PCR with the following cycling conditions was used: $94{ }^{\circ} \mathrm{C}$ for $4 \mathrm{~min} ; 94{ }^{\circ} \mathrm{C}$ for $1 \mathrm{~min} ; 60{ }^{\circ} \mathrm{C}$ for $1 \mathrm{~min}$; and $72{ }^{\circ} \mathrm{C}$ for $1 \mathrm{~min}$ with $0.5^{\circ} \mathrm{C}$ decrease in every cycle for 10 cycles, followed by $94{ }^{\circ} \mathrm{C}$ for $1 \mathrm{~min}, 54{ }^{\circ} \mathrm{C}$ for $1 \mathrm{~min}$, and $72{ }^{\circ} \mathrm{C}$ for $1 \mathrm{~min}$ pause at $4{ }^{\circ} \mathrm{C}$. The reaction was carried out in MJ Research PTC-225 Peltier Thermo Cycler.

\section{Denaturing gradient gel electrophoresis}

Following PCR, the amplification products were loaded on to a DGGE gel using Decode system (Bio-Rad Laboratories Inc.). Vertical polyacrylamide gel $(8 \% v / v, 1 \mathrm{~mm}$ thick) was prepared using a gradient maker from Bio-Rad Laboratories Inc. A mixture of $7 \mathrm{M}$ urea and $40 \%$ formamide was defined as $100 \%$ denaturant (Muyzer et al. 1993). Fifteen microliters of the PCR product containing $500 \mathrm{ng}$ of amplified DNA and $3 \mu \mathrm{L}$ of bromophenol blue was loaded to the gel using capillary pipette tips. Amplified bacterial DNA using $907 \mathrm{r}$ and $358 \mathrm{f}$ primer pair was run on a denaturing gradient of $30-70 \%$ for $16 \mathrm{~h}$ at $80 \mathrm{~V}$ and $60{ }^{\circ} \mathrm{C}$ in $1 \times$ TAE. Ascomycete DNA amplified with ITS1 and ITS4A primers was run on denaturing gradient of $35-50 \%$. Gel strength, run time, run temperature, and voltage remain unchanged. Migration patterns were visualized by staining the gel with 1:10,000 $(v / v)$ SYBR Gold (Invitrogen, Burlington, Ontario, Canada) in $1 \times$ TAE for
30 min followed by de-staining for the same period on a wavedancer. Images were documented under UV transillumination with the Gel Doc System (Bio-Rad Laboratories Ltd., Mississauga, Ontario). Micropipette tips (2-200- $\mu \mathrm{L}$ capacity) were used to prick bands on gel (band pricking). To avoid cross contamination of the bands, tips were placed in PCR tubes containing $5 \mu \mathrm{L}$ Gibco water only after a single contact with gel and the PCR tubes with an overlying cellophane sheet were put at $4{ }^{\circ} \mathrm{C}$ overnight. The following day, a pipette was used to mix the contents by sucking the liquid into and out of yellow tips into the PCR tube. The empty tips were then discarded and $1-\mu \mathrm{L}$ water from the PCR tubes was used to run a second PCR cycle.

The specifications for second PCR cycle in case of fungi were initial denaturation at $94{ }^{\circ} \mathrm{C}$ for $4 \mathrm{~min}$; followed by 30 cycles for $94{ }^{\circ} \mathrm{C}$ for $1 \mathrm{~min}$; annealing at $58{ }^{\circ} \mathrm{C}$ for $1 \mathrm{~min}$; extension at $72{ }^{\circ} \mathrm{C}$ for $1 \mathrm{~min}$; final elongation at $72{ }^{\circ} \mathrm{C}$ for $10 \mathrm{~min}$; and pause at $4{ }^{\circ} \mathrm{C}$. PCR conditions for second amplification cycle in case of bacteria and the DNA extraction from the DGGE gel (band pricking) remained unchanged. Primers used for the second PCR (re-amplification) cycle in case of both, fungi, and bacteria were without GC clamps. The amplification products were quantified using Gene Tools software from SYNGENE, and $10 \mu \mathrm{L}$ of amplification product containing $5 \mathrm{ng}$ of amplicon was sequenced at Biomolecular Analysis Platform of Université Laval. Due to poor sequence results, some bands in case of bacteria could be not identified and as such were left out.

\section{Data analysis}

The rRNA gene sequences (16S in case of bacteria and $18 \mathrm{~S}$ in case of fungi) were submitted for comparison to the Gene Bank databases using the BLAST algorithm (Altschul et al. 1990). The sequences were then aligned with their closest relatives using ClustalW. Phylogenetic trees (neighbor-joining algorithm) were constructed using MEGA software (version 5) (Tamura et al. 2011). The robustness of inferred topologies was tested by 1000 bootstrap re-samplings of the neighbor-joining data.

To study the similarity of sampling sites with respect to their bacterial and fungal diversity, Jaccard's similarity index (JSI) (Jaccard 1912) was used. JSI was calculated as:

$$
\frac{a}{a+b+c} \times 100
$$

where $a$ is number of species common between invaded and un-invaded sites, $b$ is number of species unique to invaded site, and $c$ is number of species unique to un-invaded site. 


\section{Results}

\section{Bacteria}

In case of bacteria, a total of 106 bands were seen on the gel (Fig. 1) which belonged to 57 different species (for presence/absence of bands, frequency, and other information please see Additional file 1: Table S1a, b). Site-wise analysis reveals that 27 species of bacteria were obtained from site I of which 12 occurred in the invaded plots and 18 in the un-invaded plots, three species were common between invaded and un-invaded plots whereas nine species were unique to the invaded plots and 15 species were unique to the un-invaded plots (Fig. 2a). JSI was calculated for invaded versus un-invaded plots based on the identified species which for the site I was of the order of $11.11 \%$.

Of the 31 species recorded at site II, invaded and uninvaded plots harbored 17 and 19 species, respectively, while five species were shared between them. Twelve bacterial species were exclusive to invaded plot sand 14 were restricted to the un-invaded plots (Fig. 2b). JSI was $16.13 \%$. At site III, 31 bacterial species were recorded; invaded and un-invaded plots harbored 20 species each. Only nine species where common between the invaded and un-invaded plots with 11 bacterial species unique in each case (Fig. 2c). JSI was higher for site III (29.03 \%) in comparison to the other two sites.

The bacterial DNA amplified from the study sites grouped mainly into Sphingobacteria and Alphaproteobacteria. No phylogenetic group, however, was distinctively favored or inhibited by C. sumatrensis invasion. At all the three sites, the bacterial groups that were shared between invaded and un-invaded plots were not present in the same abundance at the two kinds of plots, e.g., Sphingobacteria formed $34 \%$ of the identified sequences in the invaded plots but only $16 \%$ in the un-invaded plots; Betaproteobacteria which formed $13 \%$ of the total identified sequences in the invaded plots formed only $8 \%$ in the un-invaded plots. Cyanobacteria were found in the invaded plots whereas Acidobacteria occurred exclusively in un-invaded plots.

\section{Fungi}

In respect of fungi, the total number of bands obtained on gels was 60 which comprised 35 different species (Fig. 3) (for presence/absence of bands, frequency, and other information please see Additional file 1: Table S2a, b).

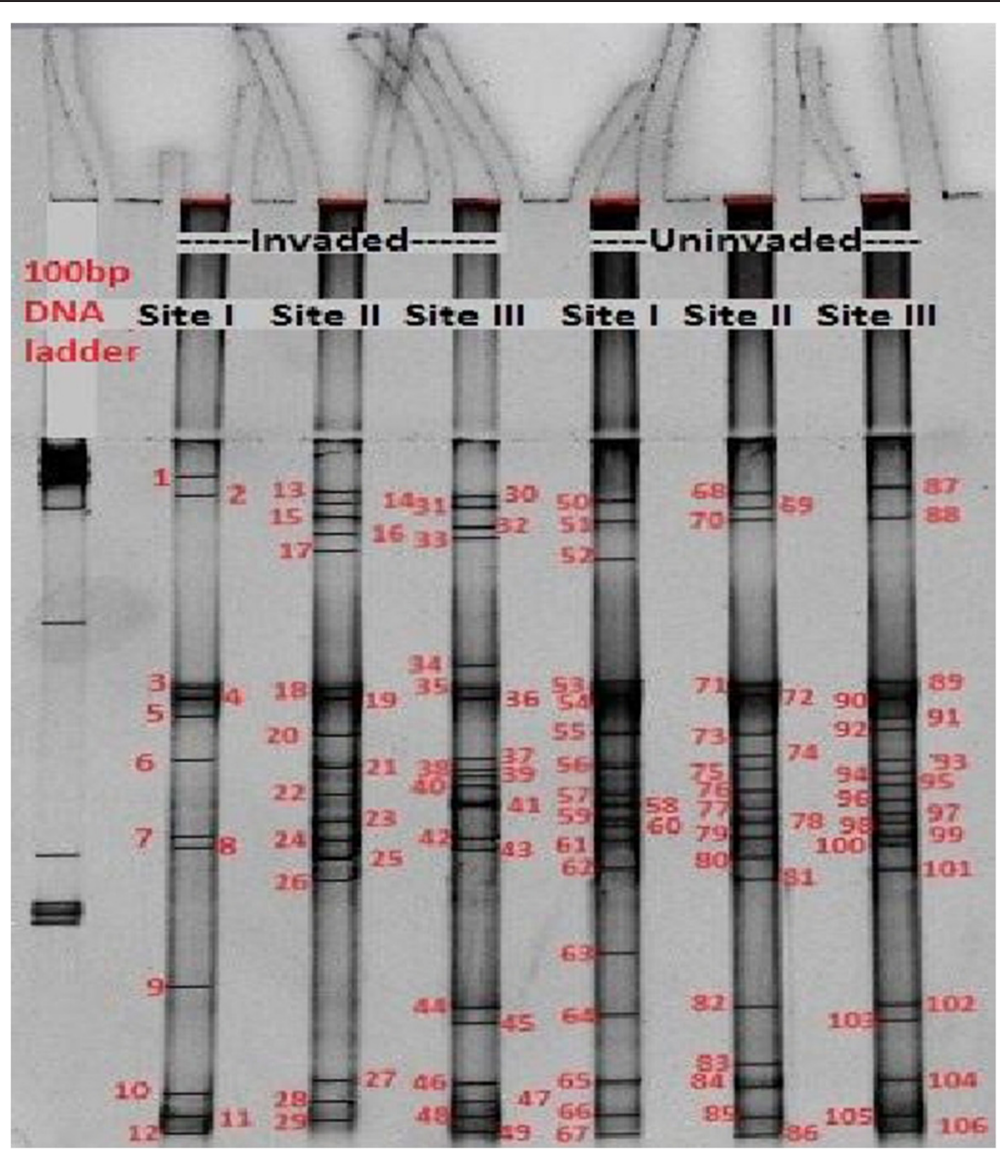

Fig. 1 DGGE analysis of 165 ribosomal DNA (rDNA) fragments amplified from rhizospheric soil of Conyza sumatrensis at the three urban invaded sites and their respective un-invaded controls 


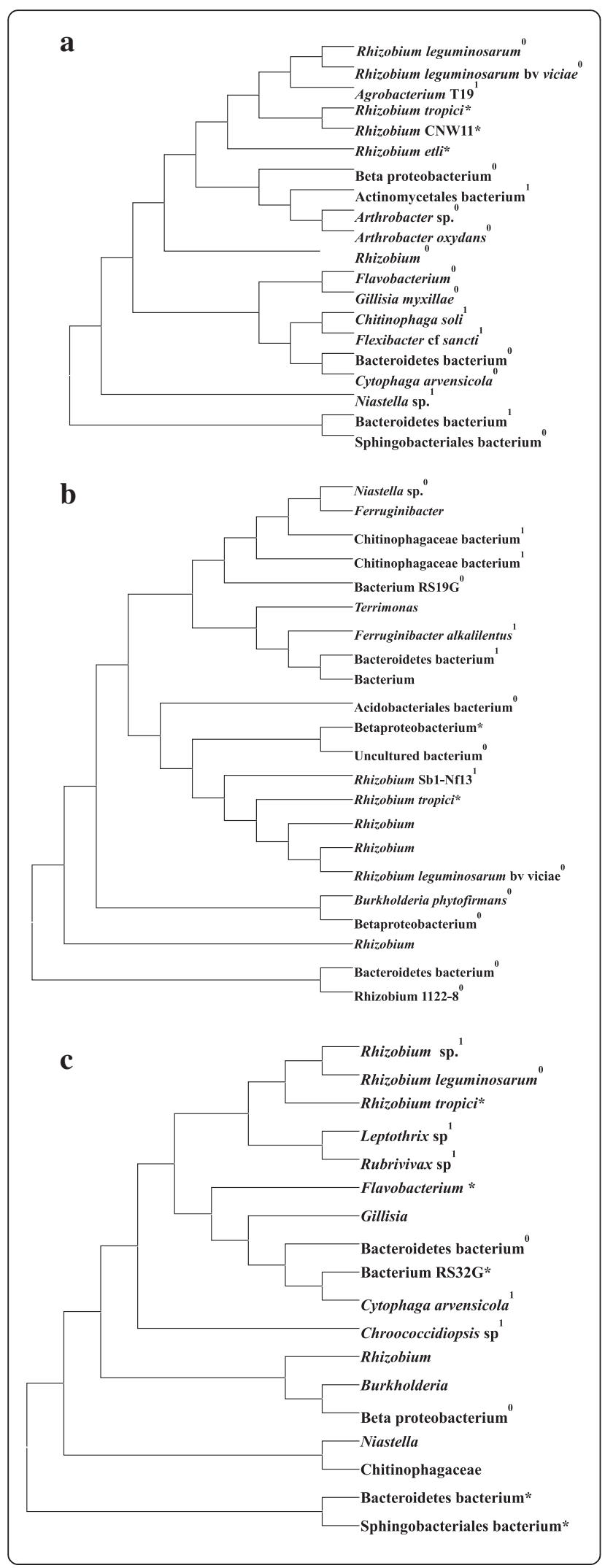

Fig. 2 Neighbor-joining tree representing the phylogenetic relationships of bacterial OTU sequences from the plots invaded and un-invaded by Conyza sumatrensis at site I (a), site II (b), and site III (c). The number of bootstrap replications was fixed at 1000. $0=$ species in the un-invaded plot; $1=$ species in the invaded plot; and ${ }^{*}=$ species common between invaded and un-invaded plots

The number of species belonging to Ascomycetes recorded from the site I was 17 of which 12 were reported from the invaded plots and seven from un-invaded plots; two species were found to be common between invaded and uninvaded plots. Ten species were restricted to invaded plots whereas five occurred exclusively in un-invaded plots (Fig. 4a). JSI was found to be $11.76 \%$. At site II, seven species were recorded from the invaded plots and six from uninvaded plots and one species was common between invaded and un-invaded plots. Thus, the total number of species at this site was 12 . Six species occurred only in invaded plots and five species only in un-invaded plots (Fig. 4b). JSI for the site II was $8.33 \%$. Twenty-five species were recorded from site III, 16 from invaded plots, and 12 from un-invaded plots; three species were common between invaded and un-invaded plots whereas 13 and 9 species were unique to invaded and un-invaded plots, respectively (Fig. 4c). JSI for the site was $12.0 \%$.

The species composition of invaded and un-invaded plots was found to be distinct (Fig. 4a-c). Among the six species of Davidiellaceae, only two, namely Cladosporium pseudocladosporioides and Cladosporium xylophilum, were common between invaded and un-invaded plots; others occurred exclusively in the un-invaded plots. Likewise, three species of Pleosporaceae, out of a total of five members, occurred only in C. sumatrensis invaded plots and both the members of Mycosphaerellaceae were also found only in the invaded plots. Peziza subcitrina (Pezizaceae), Paraphoma chrysanthemicola (Phaeosphaeriaceae), and Penicillium sp. (Trichocomaceae) were also confined to invaded plots. Pleosporaceae was more species rich in the invaded plots where three species of this family occurred. Likewise, members of Mycosphaerellaceae, Phaeosphaeriaceae, Trichocomaceae, and Ascobolaceae were exclusive to plots invaded by $C$. sumatrensis. As in case of bacteria, the abundance of those fungi that occurred in both invaded and un-invaded plots also varied between these plots. While Davidiellaceae included only $8 \%$ of the total of 24 identified species in the invaded plots, it represented $40 \%$ of the total identified species in the un-invaded plots. Pleosporaceae represented $20 \%$ of the identified species in the invaded plots but only $13 \%$ in the un-invaded plots. In contrast to exclusive occurrence of certain species to either invaded or un-invaded plots, the only representative of Myxotrichaceae occurred in both invaded and un-invaded plots. Didymellaceae was represented by two members, one of which, namely 


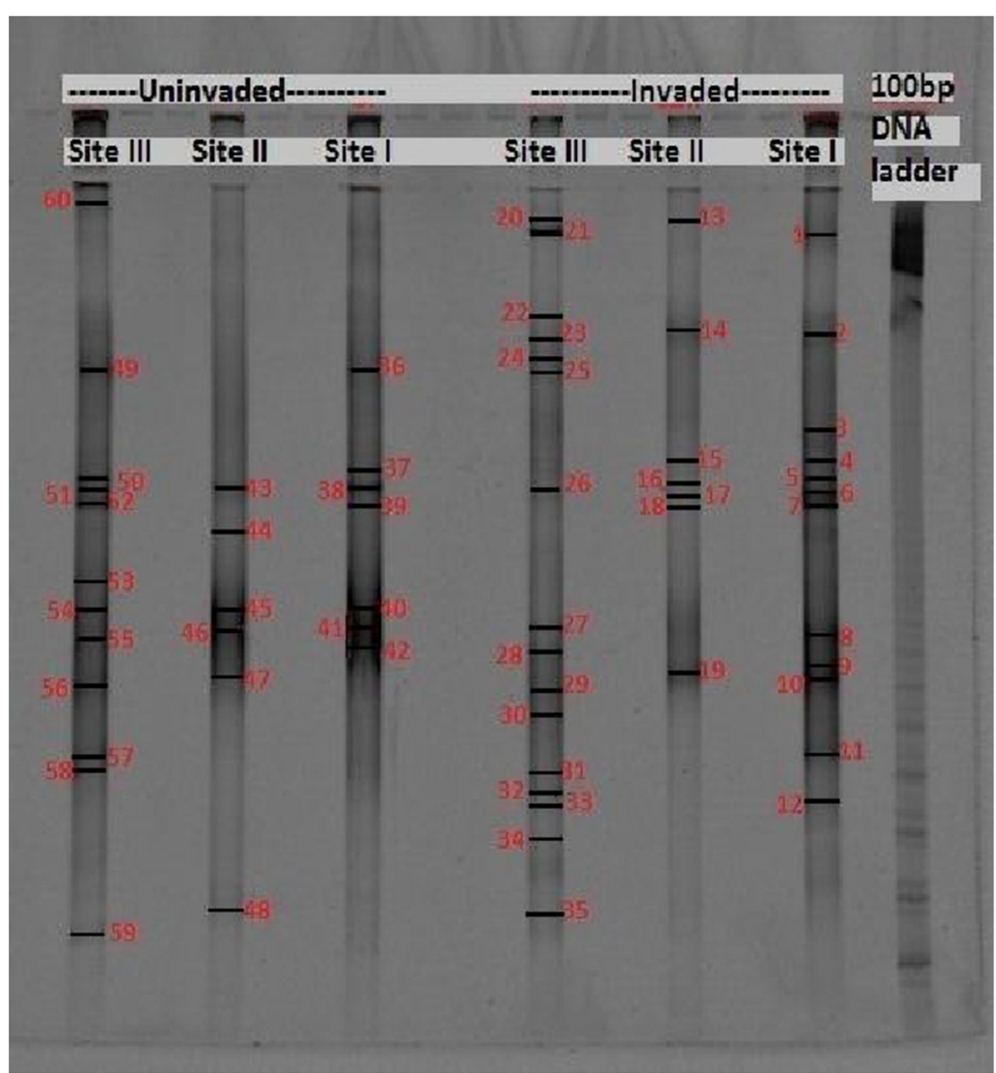

Fig. 3 DGGE analysis of 185 rDNA fragments amplified from rhizospheric soil of Conyza sumatrensis at the three invaded sites and their respective un-invaded controls

Didymella phacae occurred in invaded plots while the other Leptosphaerulina americana was common to invaded and un-invaded plots.

\section{Discussion}

Our results revealed that $C$. sumatrensis alters soil microbial diversity in the invaded urban ecosystems of Kashmir Himalaya. Though we expected this species to reduce the soil microbial diversity because Conyza is known to decrease significantly the aboveground diversity (Shah et al. 2014a), the results obtained were rather inconsistent. For instance, while the diversity of bacteria was less at two of the three invaded sites, at the third site, the number of species at invaded and un-invaded plots was not different, though the nature of species was considerably different. Whether Conyza-driven decrease in native plant species richness in non-native ranges but not at home (Shah et al. 2014a) may be linked to alter belowground microbial species diversity in Conyza invaded vs. un-invaded plots needs further investigation. However, overall decrease in the number of bacterial species and number of species occurring exclusively in invaded plots as compared to that in un-invaded plots, at least at two sites, is indicative of the influence of aboveground diversity on belowground diversity. In an earlier study, soil bacterial diversity has been shown to be reduced following invasion by Flaveria bidentis (Yan et al. 2011) and significant difference in the diversity between invaded and un-invaded stands has also been reported (Yannarell et al. 2011). Findings of the present study contradict the viewpoint that bacteria which occur inside soil aggregates and other small pores associated with clay particles may not be subject to fluctuations of microclimate in their habitat (Blankinship et al. 2011; Bushby and Marshall 1977; Denef et al. 2001; Hattori 1988 ) and, therefore, may not be influenced much by the alterations in their environment.

In contrast to bacteria, the fungal diversity was positively influenced by Conyza invasion. At site I, invaded plots recorded 12 species with 10 species occurring exclusively in these plots whereas un-invaded plots recorded seven species with only five species exclusive to them. The total number of species was seven and six and the number of species occurring exclusively in invaded and un-invaded plots six and five, respectively, at site II. For site III, the total number of species and the number of unshared species at invaded and un-invaded plots were 16 and 13 and 12 and 9, respectively. In a 

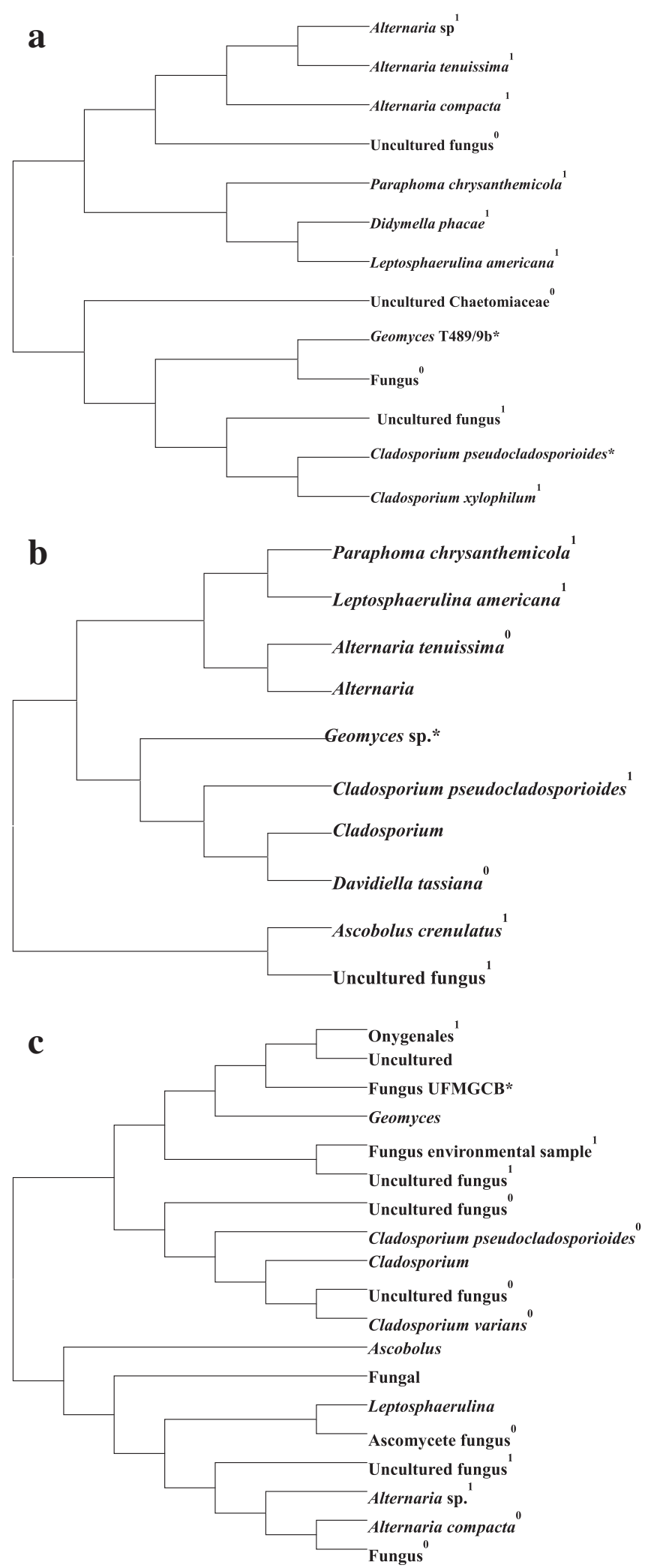

Fig. 4 Neighbor-joining tree representing the phylogenetic relationships of fungal OTU sequences from the plots invaded and un-invaded by Conyza sumatrensis at site I (a), site II (b), and site III (c). The number of bootstrap replications was fixed at 1000. 0 = species in the un-invaded plot; $1=$ species in the invaded plot and ${ }^{*}=$ species common between invaded and un-invaded plots 
recent study, invasion by Chromolena odorata was reported to increase fungal biomass (Xiao et al. 2014). However, contrary to the observations in the present study, fungal diversity has been reported to decrease after Centaurea maculosa (Broz et al. 2007; Klein et al. 2006; Lutgen and Rillig 2004; Mummey and Rillig 2006) and Alliaria petiolata invasion (Callaway et al. 2008). Shah et al. (2014b) found that Conyza draws positive feedback from soil biota and this contributes towards its invasiveness.

Microbial community composition in the rhizosphere is affected by a complex interaction between soil type, plant species, and root zone location. Besides, allelopathy could profoundly influence the interactions of a species with its neighbors. The allelopathic arsenal of Conyza includes a variety of phenolic compounds like vanillic acid, catechol, gallic acid, and syringic acid in addition to growth promoters like phytohormones (Shaukat et al. 2003). The free phenol content increases steadily from flowering to fruiting stages in this Conyza species (Djurdjević et al. 2012). Phenols stimulate microbial growth at lower concentrations and inhibit it at higher concentrations ( $\mathrm{Qu}$ and Wang 2008). For example, Achromobacter species can be grown in $0.1 \%$ phenol; however, higher concentrations may be inhibitory for growth or may even kill the bacteria (Czekalowski and Skarzynski 1948). Phenols affect membrane potentials and membrane permeability (Denyer 1995). Phenols may directly influence nutrient turnover and microbial activity and biomass (Wardle et al. 1998) reducing abundance of a species or causing complete disappearance of a species, thereby, disturbing the existing microbial biodiversity (Hussain and Reigosa 2011; Hussain et al. 2011; Djurdjević et al. 2011; Djurdjević et al. 2012). Bacteria and fungi differ in their tolerance to phenolic compounds; many fungi are known to utilize phenols as a carbon source (Ander and Eriksson 1976). Thus, the results in the present study, to a great extent, can be explained on the basis of effects of phenols on soil microbial community members besides trait differences between native and invasive plant species, as the difference in the quality, quantity, and timing of organic matter inputs has consequences for soil food web (Wardle et al. 2004), including taxonomic or functional diversity within major groups of soil organisms. In conformity with our results, several earlier workers (e.g., Callaway et al. 2004; Jordan et al. 2008; KaoKniffin and Balser 2007; Reinhart and VandeVoort 2006; Sanon et al. 2009) have reported altered microbial community structure following plant invasion. It appears, however, that invasive plants may not necessarily cause biotic homogenization below ground which is so well marked an effect of these plants above ground. Characteristics of the invasive plant, its stage of growth, and characteristics of the site invaded manipulate the outcome of invasion (Belnap and Philips 2001, Bolton et al. 1990; Evans et al. 2001; Meyerson et al. 2000; Scott et al. 2001; Stock et al. 1995). Hence, the need for studying the phenomenon of invasion in diverse ecosystems involving different invasive species to have a better understanding of the impact of invasive plants on ecosystem structure and function, especially with reference to belowground microbial communities cannot be overstressed.

\section{Conclusions}

Overall, our results allow us to conclude that C. sumatrensis does alter the soil microbial diversity in the invaded habitats. Not only it reduces the bacterial species diversity in invaded plots but also some bacterial species are characteristically restricted only to plots invaded by this species. Similarly, fungal species richness was also higher in the invaded as compared to the uninvaded plots at all the three sites with some species restricted exclusively to the invaded plots. Unraveling the mechanism of how C. sumatrensis changes soil microbial communities and whether it draws these communities to its advantage at the cost of native species promises to be an interesting future discourse. Equally interesting is to understand how this invasion-induced change in soil microbial community composition influences native plant species in the invaded urban ecosystems.

\section{Additional file}

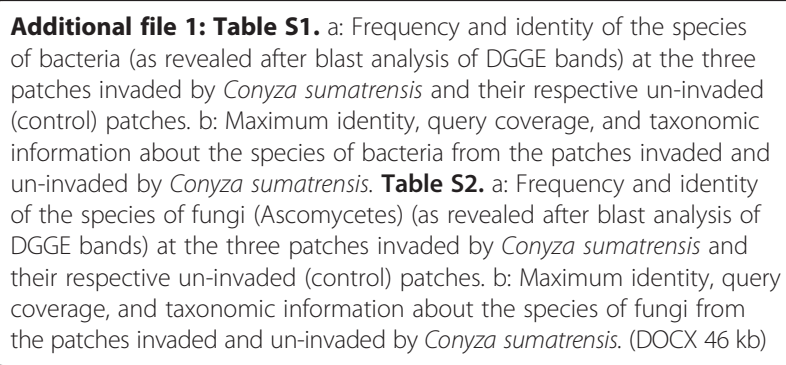

Competing interests

The authors declare that they have no competing interests.

\section{Authors' contributions}

NR carried out the experimental work together with MAS. NR wrote the first draft which was edited by MAS and proofread by DPK and ZAR. All the authors thus actively contributed towards the preparation of the manuscript.

\section{Acknowledgements}

The grant provided by the Canadian Bureau of International Education (CBIE) to NR for conducting the present study is gratefully acknowledged.

\section{Author details}

${ }^{1}$ Biological Invasion Laboratory, Department of Botany, University of Kashmir, Srinagar 190 006, Jammu and Kashmir, India. ${ }^{2}$ Canadian Research Chair in

Forest and Environmental Genomics and Institute of Integrative and Systems Biology, Pavillon Marchand, Université laval, Québec G1V 0A6, Canada.

Received: 14 October 2015 Accepted: 23 June 2016

Published online: 29 June 2016 


\section{References}

Altschul S, Gish W, Miller W, Myers EW, Lipman DJ (1990) Basic local alignment search tool. J Mol Biol 215:403-410

Anastasiu P, Memedemin D (2011) Conyza sumatrensis: a new alien plant in Romania. Botanica Serbica 36:37-40

Ander P, Erickson KE (1976) The importance of phenoloxidase activity in lignin degradation by the white-rot fungi Sporotrichum pulvurulentum. Arch Microbiol 109:1-8

Belnap J, Phillips SL (2001) Soil biota in ungrazed grassland: response to annual grass (Bromus tectorum) invasion. Ecol Appl 11:1261-1275

Blankinship CJ, Niklaus PA, Hungate BA (2011) A meta-analysis of responses of soil biota to global change. Oecologia 165:553-565

Bohlen PJ (2006) Biological invasions: linking the aboveground and belowground consequences. Appl Soil Ecol 32:1-5

Bolton H, Smith JL, Wildung RE (1990) Nitrogen mineralization potentials of shrubsteppe soils with different disturbance histories. Soil Sci Soc Am J 54:887-891

Broz AK, Manter DK, Vivanco JM (2007) Soil fungal abundance and diversity: another victim of the invasive plant Centaurea maculosa. ISME J 1:763-765

Bushby HVA, Marshall KC (1977) Some factors affecting the survival of rootnodule bacteria on desiccation. Soil Biol Biochem 9:143-147

Callaway RM, Thelen GC, Bartha S, Ramsey PW, Gannon JE (2004) Soil fungi interactions between the invader Centaurea maculosa and North American natives. Ecology 85:1062-1071

Callaway RM, Cipollini D, Barto K, Thelen GC, Hallet SG, Prati D, Stinson K, Klironomos J (2008) Novel weapons: invasive plant suppresses fungal mutualists in America but not in its native. Eur Ecol 89:1043-1055

Czekalowski JW, Skarzynski B (1948) The breakdown of phenols and related compounds by bacteria. J Gen Microbiol 2:231-238

Dar P, Reshi Z, Shah MA (2015) Roads act as corridors for the spread of alien plant species in the mountainous regions: a case study of Kashmir Valley, India. Tropical Ecol 56(2):183-190

Denef K, Six J, Bossuyt H, Frey SD, Elliott ET, Merckx R, Paustian K (2001) Influence of dry-wet cycles on the interrelationship between aggregate, particulate organic matter, and microbial community dynamics. Soil Biol Biochem 33:1599-1611

Denyer SP (1995) Mechanisms of action of antibacterial biocides. Int Bio Deterior Biodegrad 36:227-245

Djurdjević L, Mitrović M, Gajić G, Jarić S, Kostć O, Oberan L, Pavlović P (2011) An allelopathic investigation of the domination of the introduced invasive Conyza canadensis L. Flora 206:921-927

Djurdjević L, Gordana G, Olga K, Snežana J, Marija P, Miroslava M, Pavle P (2012) Seasonal dynamics of allelopathically significant phenolic compounds in a globally successful invader Conyza canadensis L. plants and associated soil. Flora 207:812-820

Ehrenfeld JG (2003) Effects of exotic plant invasions on soil nutrient cycling processes. Ecosystems 6:503-523

Evans RD, Rimer R, Sperry L, Belnap J (2001) Exotic plant invasion alters nitrogen dynamics in an arid grassland. Ecol Appl 11:1301-1310

Gardes M, Bruns TD (1993) ITS primers with enhanced specificity for Basidiomycetes: application to the identification of mycorrhizae and rusts. Mol Ecol 2:113-118

Hao J, Qiang S, Liu Q, Cao F (2009) Reproductive traits associated with invasiveness in Conyza sumatrensis. J Syst Evol 47(3):245-254

Hattori T (1988) Soil aggregates in microhabitats of microorganisms. Rep Inst Agric Res Tohoku University 37:23-36

Hussain MI, Reigosa MJ (2011) Allelochemical stress inhibits growth, leaf water relations, PSII photochemistry, non-photochemical fluorescence quenching, and heat energy dissipation in three C3 perennial species. J Exp Bot 62:4533-4545

Hussain MI, Gonzalez L, Souto C, Reigosa MJ (2011) Ecophysiological responses of three native herbs to phytotoxic potential of invasive Acacia melanoxylon $\mathrm{R}$. Br. Agroforestry Syst 83:149-166

Jaccard P (1912) The distribution of the flora of the alpine zone. New Phytol 11:37-50

Jordan NR, Larson DL, Huerd SC (2008) Soil modification by invasive plants: effects on native and invasive species of mixed-grass prairies. Biol Invasions 10:177-190

Kao-Kniffin J, Balser TC (2007) Soil fertility and the impact of exotic invasion on microbial communities in Hawaiian forests. Microb Ecol 56:55-63

Klein DA, Paschke MW, Heskett TL (2006) Comparative fungal responses in managed plant communities infested by spotted (Centaurea maculosa Lam.) and diffuse (C. diffusa Lam.) knapweed. Appl Soil Ecol 32:89-97

Kourtev PS, Ehrenfeld JG, Häggblom M (2002) Exotic plant species alter the microbial community structure and function in the soil. Ecology 83:3152-3166
Lane D, Pace B, Olsen GJ, Stahl DA, Sogin ML, Pace NR (1985) Rapid determination of 165 ribosomal RNA sequences for phylogenetic analyses. Proc Natl Acad Sci U S A 82:6955-6959

Lavoie C (2010) Should we care about purpleloose strife? The history of an invasive plant in North America. Biol Invasions 12:1967-1999

Li WH, Zhang CB, Jiang HB, Xin GR, Yang ZY (2006) Changes in soil microbial community associated with invasion of the exotic weed, Mikania micranth $\mathrm{H}$. B. K. Plant Soil 281:309-324

Liao C, Peng R, Luo YQ, Zhou XH, Wu XW, Fang C, Chen J, Li B (2008) Altered ecosystem carbon and nitrogen cycles by plant invasion: a meta-analysis. New Phytol 177:706-714

Lutgen ER, Rillig MC (2004) Influence of spotted knapweed (Centaurea maculosa) management treatments on arbuscular mycorrhizae and soil aggregation. Weed Sci 52:172-177

Marchante E, Kjøller A, Struwe S, Freitas H (2008) Short and long-term impacts of Acacia longifolia invasion on the belowground processes of a Mediterranean coastal dune ecosystem. Appl Soil Ecol 40(2):210-217

McCullough DG, Work T, Cavey JF, Liebhold AM, Marshall D (2006) Interceptions of nonindigenous plant pests atUS ports of entry and border crossings over a 17-year period. Biol Invasions 8:611-630

McKinney ML (2004) Do exotics homogenize or differentiate communities? Roles of sampling and exotic species richness. Biol Invasions 6:495-504

McKinney ML, Lockwood JL (1999) Biotic homogenization: a few winners replacing many losers in the next mass extinction. Trends Ecol Evol 14:450-453

Meyerson LA, Saltonstall K, Windham L, Kiviat E, Findlay S (2000) A comparison of Phragmites australis in freshwater and brackish marsh environments in North America Wetland. Ecol Manage 9:89-103

Mummey DL, Rillig MC (2006) The invasive plant species Centaurea maculosa alters arbuscular mycorrhizal fungal communities in the field. Plant Soil 288:81-90

Muyzer G, de Waal EC, Uitterlinden AG (1993) Profiling of complex microbial populations by denaturing gradient gel electrophoresis analysis of polymerase chain reaction-amplified genes coding for 16S rRNA. Appl Environ Microbiol 59:695-700

Nie M, Gao LX, Yan JH, Fu XH, Xiao M, Yang J, Li B (2010) Population variation of invasive Spartina alterniflora can differentiate bacterial diversity in its rhizosphere. Plant Ecol 209:219-226

Perrings C, Dehnen-Schmutz K, Touza J, Williamson M (2005) How to manage biological invasions under globalization. Trends Ecol Evol 20:212-215

Qu XH, Wang JG (2008) Effect of amendments with different phenolic acids on soil microbial biomass, activity, and community diversity. Appl Soil Ecol 39(2):172-179

Reinhart KO, VandeVoort R (2006) Effect of native and exotic leaf litter on macroinvertebrate communities and decomposition in a western Montana stream. Divers Distrib 12:776-781

Rooney TP, Wiegmann SM, Rogers DA, Waller DM (2004) Biotic impoverishment and homogenization in unfragmented forest understory communities. Conserv Biol 18:787-798

Sanon A, Béguiristain T, Cébron A, Berthelin J, Ndoye I, Leyval C, Sylla S, Duponnois R (2009) Changes in soil diversity and global activities following invasions of the exotic invasive plant, Amaranthus viridis L., decrease the growth of native sahelian Acacia species. FEMS Microbiol Ecol 70:118-131

Sansom M, Saborido AA, Dubois M (2013) Control of Conyza spp. with glyphosate-a review of the situation in Europe. Plant Protect Sci 49:44-53

Santos G, Oliveira RS Jr, Constantin J, Francischini AC, Machado MFPS, Mangolin CA, Nakajima JN (2014a) Conyza sumatrensis: a new weed species resistant to glyphosate in the Americas. Weed Biology and Management 14:106-114

Santos G, Oliveira RS Jr, Constantin J, Francischini AC, Osipe JB (2014b) Multiple resistance of Conyza sumatrensis to chlorimuronethyl and to glyphosate. Planta Daninha 32:409-416

Scott N, Saggar S, Mclntosh PD (2001) Biogeochemical impact of Hieracium invasion in New Zealand's grazed tussock grasslands: sustainability implications. Ecol Appl 11:1311-1322

Shah MA, Callaway RM, Shah T, Houseman GR, Pal RW, Xiao S, Luo W, Rosche C, Reshi ZA, Khasa DP, Chen S (2014a) Conyza canadensis suppresses plant diversity in its nonnative ranges but not at home: a transcontinental comparison. New Phytol 202:1286-1296

Shah T, Shah MA, Reshi Z (2014b) Positive feedback from soil microbes promotes invasion by Conyza canadensis. J Himalayan Ecol Sustain Dev 9:17-22

Shah MA, Beaulieu ME, Reshi ZA, Qureshi S, Khasa DP (2015) A cross-city molecular biogeographic investigation of arbuscular mycorrhizas in Conyza canadensis rhizosphere across native and non-native regions. Ecol Process 4:7 
Shaukat SS, Munir N, Siddiqui A (2003) Allelopathic response of Conyza canadensis (L.) cronquist: a cosmopolitan weed. Asian J Plant Sci 2:1034-1039

Simberloff D, Von Holle B (1999) Positive interactions of non-indigenous species: invasional meltdown? Biol Invasions 1:21-32

Stock WD, Wienand KT, Baker AC (1995) Impacts of invading $\mathrm{N}_{2}$-fixing Acacia species on patterns of nutrient cycling in two Cape ecosystems: evidence from soil incubation studies and ${ }^{15} \mathrm{~N}$ natural abundance values. Oecologia 101:375-382

Tamura K, Peterson D, Peterson N, Stecher G, Nei M, Kumar S (2011) MEGA5: molecular evolutionary genetics analysis using maximum likelihood, evolutionary distance, and maximum parsimony method. Mol Biol Evol 28:2731-2739

Taylor CM, Davies HG, Civilli JC, Grevstad FS, Hastings A (2004) Consequences of an Allee effect on the invasion of pacific estuary Spartina alterniflora. Ecology 85:3254-3266

Thebaud C, Abbott RJ (1995) Characterization of invasive Conyza species (Asteraceae) in Europe: quantitative trait and isozyme analysis. Am J Bot 82:360-368

Wardle DA, Nilsson MC, Gallet C, Zackrisson O (1998) An ecosystem-level perspective of allelopathy. Biol Rev 73:305-319

Wardle DA, Bardgett RD, Klironomos JN, Setälä H, van der Putten WH, Wall DH (2004) Ecological linkages between aboveground and belowground biota. Science 304:1629-1633

White TJ, Bruns TD, Lee SB, Taylor JW (1990) Amplification and direct sequencing of fungal ribosomal RNA genes for phylogenetics. In: Innis MA, Gelfand DH, Sninsky JJ, White TJ (eds) PCR protocols: a guide to methods and applications. Academic, New York, pp 315-322

Wolfe BE, Klironomos JN (2005) Breaking new ground: soil communities and exotic plant invasion. Bio Sci 55(6):477-487

Xiao HF, Feng YL, Schaefer DA, Yang XD (2014) Soil fungi rather than bacteria were modified by invasive plants, and that benefited invasive plant growth. Plant Soil 378:253-264

Yan S-L, Huangfu C-H, Li G, Zuo Z-J, Ma J, Yang D-L (2011) Effects of replacement control with four forage species on bacterial diversity of soil invaded by Flaveria bidentips. Chin J Plant Ecol 35(1):45-55

Yannarell AC, Busby RR, Denight ML, Gebhart DL, Taylor SJ (2011) Soil bacteria and fungi respond on different spatial scales to invasion by the legume Lespedeza cuneata. Front Microbiol 2:127

Yelenik SG, Stock WD, Richardson DM (2004) Ecosystem level impacts of invasive Acacia saligna in the South African fynbos. Restor Ecol 12:44-51

Zhang Q, Yang R, Tang J, Yang H, Hu S, Chen X (2010) Positive feedback between mycorrhizal fungi and plants influences plant invasion success and resistance to invasion. PLoS One 5(8):e12380

\section{Submit your manuscript to a SpringerOpen ${ }^{\circ}$ journal and benefit from:}

- Convenient online submission

- Rigorous peer review

- Immediate publication on acceptance

- Open access: articles freely available online

- High visibility within the field

- Retaining the copyright to your article

Submit your next manuscript at $\gg$ springeropen.com 